\title{
LE MOUVEMENT SOCIAL
}

- N U MÉRO $259-A V R I L-J U I N 2017$

\section{L'Internationale des historiens}

Philippe Minard Éditorial : Les passeurs de frontières

Mark Mazower Devenir Hobsbawm : une internationalisation de la profession historienne

Maxine Berg Dialogues Est-Ouest : les historiens économistes, la guerre froide et la détente

\section{Quantifier la Grande Guerre}

Laurent Beau Du local au national : une nouvelle approche des pertes de 1914-1918 par département

François Robert L'impact économique du moratoire et de l'encadrement des loyers (Lyon, 1914-1926)

\section{L'impossible déchéance de nationalité}

Alexandre Dupont L'État français face au volontariat militaire pro-carliste (1872-1876)

\section{Notes DE LECTURE}

Trajectoires intellectuelles - Le rôle des banques - Reconstructions ÉCONOMIQUES - L'EMPREINTE DE LA GUERRE - LES MORTS DE GUERRE - LA MORT ET AU-DELÀ 


\section{Copying}

All rights reserved. No part of this publication may be reproduced, unless by the author, in any form or by any means, electronic, photocopying, or otherwise, without permission in writing from Cambridge University Press or, in the USA, through agreement with the Copyright Clearance Center. Policies, request forms and contacts are available at: cambridge.org/action/ rightsAndPermissions

\section{GUIDELINES FOR CONTRIBUTORS}

Submission of an article is taken to imply that it has not previously been published and is not being considered for publication elsewhere. Authors are also asked to provide brief details of any book they are publishing which includes all or part of a submitted article. Articles should be submitted in two paginated versions as soft copy (preferably by e-mail), one version containing the author's details, the other anonymized as far as possible, in order to facilitate "blind" refereeing. Authors should also include an abstract not exceeding 150 words, specifying the principal conclusion and methods in the context of currently accepted views on the subject. The files should be saved either in a recent version of MSWord for Windows, or in an MSWord compatible format, or as a PDF file. In case of doubt, please contact the editorial staff at: irsh@iisg.nl. Footnote commands should be used to create footnotes. Notes should be confined, as far as possible, to necessary references.

Manuscripts should be in British English (or American English for American authors). In cases where no English text can be provided, authors should always contact the executive editor before submitting an article.

\section{Sample citation forms}

Book: E.P. Thompson, The Making of the English Working Class (London, 1963), pp. 320-322. Journal: Walter Galenson, "The Unionization of the American Steel Industry", International Review of Social History, 1 (1956), pp. 8-40.

Detailed instructions for contributors are available from http://socialhistory.org/en/irshinstructions-contributors. It is essential that contributors observe the journal's stylistic conventions closely. If not, their articles may be returned for amendment.

\section{DISCLAIMER}

The Internationaal Instituut voor Sociale Geschiedenis (IISG) has used its best endeavours to ensure that the URLs for external websites referred to in this journal are correct and active at the time of going to press. However, the IISG has no responsibility for the websites and can make no guarantee that a site will remain live or that the content is or will remain appropriate.

Every effort has been made to trace all copyright holders, but if any have been inadvertently overlooked the Internationaal Instituut voor Sociale Geschiedenis (IISG) will be pleased to include any necessary credits in any subsequent issue.

This journal issue has been printed on FSC-certified paper and cover board. FSC is an independent, non-governmental, not-for-profit organization established to promote the responsible management of the world's forests. Please see www.fsc.org for information.

Cover image: Soldiers, counsellors, clergymen, labourers, craftsmen, merchants, 14 th c. (second half) (1376). Royal Library of Belgium; KBR, ms. 11201-02, fol. 263. Used with permission. 


\section{international review of social history}

\section{ARTICLES}

389 "I Thought of It at Work, in Ostend": Urban Artisan Labour and Guild Ideology in the Later Medieval Low Countries

Jan Dumolyn

\section{SPECIAL THEME}

421 Charismatic Leadership and Networks in Anarchism: The Cases of Pietro Gori and Jean Grave: An Introductory Note

Jan Willem Stutje

425 Pietro Gori's Anarchism: Politics and Spectacle (1895-1900)

Emanuela Minuto

451 Jean Grave and French Anarchism: A Relational Approach (1870s-1914)

Constance Bantman

\section{SUGGESTIONS AND DEBATES}

479 Globalising Migration History: A Discussion Dossier Jan Lucassen and Leo Lucassen

481 The Beginnings of a World History of Modern Migration: The Lucassens's Volume on Globalising Migration History

Patrick Manning

495 Obliterating Boundaries, Questioning Borders: A Comment on Globalising Migration History Leslie Page Moch

501 Studying Migration on a Global Scale Lynn Hollen Lees

509 Reservations About an Evolutionary Approach to Cross-Border Mobility Leo Douw

521 Migration Over Cultural Boundaries: A Rejoinder Jan Lucassen and Leo Lucassen

\section{REVIEW ESSAY}

537 Atlas Stirs: The Promises and Complexities of a Global History of Social Movements Marc Steinberg

551 Book Reviews

571 Bibliography

599 Referees 2014-2016

Cambridge Core

For further information about this journal please go to the journal website at: cambridge.org/ish
MIX

Paper from responsible sources Fww.fsc.org FSC $^{\odot}$ C007785

CAMBRIDGE UNIVERSITY PRESS 